\title{
Cerebral blood flow and oxygen uptake, and cerebrospinal fluid biochemistry in severe coma ${ }^{1}$
}

\author{
POUL BRODERSEN² AND ERIK O. JØRGENSEN \\ From the Departments of Neurology, Clinical Physiology, Anaesthesiology, and Psychiatry, \\ Bispebjerg Hospital, and Medical Department B, Rigshospitalet, Copenhagen, Denmark
}

SYNOPSIS Thirty-eight patients in coma due to head trauma, cerebrovascular accidents, hypoxia, hypoglycaemia, or barbiturate intoxication, and 15 cases of brain death were studied. Cerebral metabolic rate of oxygen $\left(\mathrm{CMRO}_{2}\right)$ was obtained from the arteriovenous oxygen difference and cerebral blood flow (CBF) measured by intra-arterial ${ }^{133}$ Xenon method. If hypothermia and CNS depressants were excluded, $\mathrm{CMRO}_{2}$ below one-third of normal was incompatible with regaining of consciousness, but this was seen in only three comatose patients. Irrespective of the clinical outcome (death, vegetative survival, or recovery), $\mathrm{CMRO}_{2}$ values of one-third to two-thirds of normal were seen in the majority of coma patients. $\mathrm{CMRO}_{2}$ measurements were of no practical value to predict the prognosis in coma, even when the effect of temperature and sedatives were considered. In brain death the CBF studies gave indirect evidence of cerebral circulatory arrest. The cerebrospinal fluid (CSF) was obtained for analysis of lactate, pyruvate, and bicarbonate in 29 cases. Increased CSF lactate levels were found in all groups except barbiturate intoxication. The finding of a negative correlation between CSF bicarbonate and log CBF suggests that the CSFpH determines the wide range of $\mathrm{CBF}$ in coma.

Kety (1949) noticed that in all conditions of semicoma or coma of whatever cause, the reduction of the level of consciousness correlated with the decrease of cerebral oxygen uptake. In coma the cerebral oxygen uptake was reduced to below $2.0 \mathrm{ml} . / 100 \mathrm{~g} / \mathrm{min}$, while the normal value for awake man is about $3.3 \mathrm{ml} . / 100 \mathrm{~g} / \mathrm{min}$ (Kety, 1949; Lassen, 1959). Shalit et al. (1970) and Shalit et al. (1972) studied cerebral blood flow (CBF) and arteriovenous oxygen difference, (a-v) $\mathrm{O}_{2}$ for obtaining the cerebral metabolic rate of oxygen $\left(\mathrm{CMRO}_{2}=(\mathrm{a}-\mathrm{v}) \mathrm{O}_{2} \times \mathrm{CBF} \times 1 / 100\right)$ in comatose neurosurgical patients. They found that patients who regained consciousness never had $\mathrm{CMRO}_{2}$ values below $1.4 \mathrm{ml} . / 100 \mathrm{~g} /$ min. When the $\mathrm{CMRO}_{2}$ was below $1.0 \mathrm{ml}$./ $100 \mathrm{~g} / \mathrm{min}$, a rapid decompensation of vital brain mechanisms such as spontaneous respiration and

\footnotetext{
1 Read as a preliminary study before the Second International Symposium on Nuclear Medicine, Karlovy Vary, 13 May 1971, and before the 20th Congress of Scandinavian Neurologists, Oslo, 17 June 1972.

2 Address for correspondence: Dr. Brodersen, Department of Neurology, Bispebjerg Hospital, DK-2400 Copenhagen NV. Denmark.
}

blood pressure regulation occurred, followed by death within a few days. Similar findings in head injury have recently been reported by Tabbador et al. (1972).

The existence of critical levels of $\mathrm{CMRO}_{2}$ might be important for assessing the prognosis in comatose patients. It has been the purpose of the present study to extend the observations of Shalit et al. (1970). In addition to $\mathrm{CBF},(\mathrm{a}-\mathrm{v}) \mathrm{O}_{2}$, and $\mathrm{CMRO}_{2}$, we studied acid-base parameters in the cerebrospinal fluid (CSF). This part of the study offered the opportunity of correlating CSF acid-base parameters to $\mathrm{CBF}$ in a variety of comatose states.

\section{METHODS}

Sixty-seven studies were performed in 53 patients. Thirty-five were in coma defined as 'unarousable unresponsiveness' (Plum and Posner, 1972) at the time of the first study. Three patients did not fit the term coma, although they were included in the Tables and Figures as comatose. One of these was stuporous 
due to a severe migraine attack. Another was in a state of wakeful unresponsiveness during recovery after cardiac arrest. The third was a cardiac arrest patient, with electroencephalogram (EEG), clinical and necropsy findings corresponding to the description of the apallic syndrome given by Ingvar and Brun (1972). Fifteen cases had brain death when initially studied, and two more patients were studied both in a state of coma and later after brain death.

The first study was usually performed within one to three days of the lesion, but in a few was delayed between four and 14 days. Six patients had two studies, and four patients had three subsequent studies. The respiration was either spontaneous, assisted, or artificial.

The general diagnosis and the outcome are given in Table 1. None of the head trauma patients had an unoperated mass lesion at the time of the study. The

TABLE 1

GENERAL DIAGNOSIS AND OUTCOME OF 53 COMATOSE PATIENTS

\begin{tabular}{|c|c|c|c|c|}
\hline & $\begin{array}{c}\text { Regained } \\
\text { conscious- } \\
\text { ness }\end{array}$ & $\begin{array}{c}\text { Remained } \\
\text { in } \\
\text { coma }\end{array}$ & $\begin{array}{l}\text { Brain } \\
\text { death }\end{array}$ & Total \\
\hline Head trauma & 2 & 4 & 4 & 10 \\
\hline Cerebrovascular lesions & 2 & 2 & 4 & 8 \\
\hline Prolonged hypoglycaemia & - & 3 & - & 3 \\
\hline Hypoxia & 2 & 13 & 7 & 22 \\
\hline Barbiturate intoxication & 8 & - & - & 8 \\
\hline $\begin{array}{l}\text { Others (brain abscess, } \\
\text { brain tumour) }\end{array}$ & - & - & 2 & 2 \\
\hline Total & 14 & 22 & 17 & 53 \\
\hline
\end{tabular}

Out of 14 patients, who regained consciousness, only the eight with barbiturate intoxication recovered completely, whereas the other six patients showed signs of intellectual reduction and/or focal neurological deficit. cerebrovascular group comprised five patients with subarachnoid haemorrhage due to ruptured aneurysms, two cases of intracerebral haemorrhage, and one severe migraine attack. The hypoxia group comprised three patients with a brain lesion (infarct of encephalitis) combined with respiratory insufficiency, four patients with carbon monoxide intoxication, and 10 patients resuscitated for cardiac arrest; five patients in the hypoxia group had cardiac arrest complicating a barbiturate intoxication. Eight patients were in deep coma due to severe barbiturate overdose.

The following criteria were fulfilled for a diagnosis of brain death: deep coma with no spontaneous movements or reaction to painful stimuli except spinal reflexes (Jørgensen and Brodersen, 1971); irreversible loss of spontaneous respiration and cranial nerve reflexes; a flat EEG recorded for 30 minutes. If intoxication with central nervous system (CNS) depressants were suspected or if body temperature were $32^{\circ} \mathrm{C}$ or below, carotid or aortocervical angiography was carried out before the diagnosis of brain death was accepted.

Cerebral blood flow was measured using the internal carotid ${ }^{133}$ Xenon injection method (HøedtRasmussen et al., 1966; Paulson et al., 1969; Olesen et al., 1971). Either a single $5 \mathrm{~cm}$ diameter detector or multiple detector equipments with 16 or 35 small detectors were used. The bulb of the internal jugular vein was punctured and simultaneous samples obtained for determination of the (a-v) $\mathrm{O}_{2}$ and the venoarterial lactate difference, ( $v-a)$ lactate. After the flow study a lumbar puncture was performed if the clinical state did not contraindicate this procedure. The CSF pressure was measured and $5 \mathrm{ml}$. CSF was withdrawn for lactate, pyruvate, and bicarbonate analysis.

Lactate and pyruvate were determined in blood

TABLE 2

CEREBRAL BLOOD FLOW AND RELATED PARAMETERS IN COMA: MEDIAN AND RANGE OF MAJOR GROUPS

\begin{tabular}{|c|c|c|c|c|c|c|c|c|c|c|}
\hline & $\begin{array}{l}\text { Patients } \\
\quad \text { (no.) }\end{array}$ & $\begin{array}{l}\text { Studies } \\
\text { (no.) }\end{array}$ & $\begin{array}{l}\text { Age } \\
(y r)\end{array}$ & $\begin{array}{c}\text { Body } \\
\text { tempera- } \\
\text { ture }\left({ }^{\circ} \mathrm{C}\right)\end{array}$ & $\begin{array}{c}M A B P \\
(m m H g)\end{array}$ & $\begin{array}{c}C S F \\
\text { pressure } \\
(\text { mm } H g)\end{array}$ & $\begin{array}{c}\mathrm{PaCO}_{2} \\
(\mathrm{mmHg})\end{array}$ & $\begin{array}{c}C B F \\
(m l . / 100 \mathrm{~g} / \\
\text { min })\end{array}$ & $\begin{array}{l}(a-v) \mathrm{O}_{2} \\
(\text { vol. } \%)\end{array}$ & $\begin{array}{c}\mathrm{CMRO}_{2} \\
(\mathrm{ml} / \mathrm{l} / \mathrm{l} \mathrm{g} \mathrm{g} / \\
\mathrm{min})\end{array}$ \\
\hline Head trauma & 7 & 9 & $\begin{array}{c}26 \\
1962\end{array}$ & $\begin{array}{c}37 \cdot 0 \\
33 \cdot 7-39 \cdot 2\end{array}$ & $\begin{array}{c}96 \\
50-143\end{array}$ & - & $\begin{array}{c}35 \\
18-57\end{array}$ & $\begin{array}{c}26 \\
6-48\end{array}$ & $\begin{array}{c}5 \cdot 7 \\
3 \cdot 7-8 \cdot 1\end{array}$ & $\begin{array}{c}1 \cdot 8 \\
0 \cdot 3-2 \cdot 4\end{array}$ \\
\hline Cerebrovascular lesions & 4 & 6 & $\begin{array}{c}54 \\
23-58\end{array}$ & $\begin{array}{c}37 \cdot 0 \\
33 \cdot 0-37 \cdot 1\end{array}$ & $\begin{array}{c}99 \\
83-180\end{array}$ & $\begin{array}{c}15 \\
12-18\end{array}$ & $\begin{array}{c}32 \\
12-39\end{array}$ & $\begin{array}{c}29 \\
8-61\end{array}$ & $\begin{array}{c}7 \cdot 5 \\
4 \cdot 1-8 \cdot 6\end{array}$ & $\begin{array}{c}1 \cdot 6 \\
0 \cdot 6-2 \cdot 1\end{array}$ \\
\hline Posthypoglycaemic coma & 3 & 3 & $\begin{array}{c}47 \\
38-52\end{array}$ & $\begin{array}{c}37 \cdot 4 \\
37 \cdot 2-38 \cdot 9\end{array}$ & $\begin{array}{c}100 \\
100-110\end{array}$ & $\begin{array}{c}11 \\
7-12\end{array}$ & $\begin{array}{c}29 \\
27-30\end{array}$ & $\begin{array}{c}36 \\
27-55\end{array}$ & $\begin{array}{c}4 \cdot 3 \\
3 \cdot 9-5 \cdot 3\end{array}$ & $\begin{array}{c}1 \cdot 4 \\
1 \cdot 4-2 \cdot 4\end{array}$ \\
\hline Cardiac arrest & 9 & 13 & $\begin{array}{c}60 \\
38-77\end{array}$ & $\begin{array}{c}37 \cdot 5 \\
32 \cdot 7-39 \cdot 5\end{array}$ & $\begin{array}{c}83 \\
67-110\end{array}$ & $\begin{array}{c}14 \\
4-34\end{array}$ & $\begin{array}{c}33 \\
22-43\end{array}$ & $\begin{array}{c}24 \\
11-85\end{array}$ & $\begin{array}{c}5 \cdot 3 \\
1 \cdot 3-8 \cdot 2\end{array}$ & $\begin{array}{c}1 \cdot 4 \\
0 \cdot 4-2 \cdot 1\end{array}$ \\
\hline $\begin{array}{l}\text { Cardiac arrest and } \\
\text { barbiturate intoxication }\end{array}$ & 5 & 7 & $\begin{array}{c}56 \\
36-59\end{array}$ & $\begin{array}{c}37 \cdot 1 \\
29 \cdot 0-37 \cdot 7\end{array}$ & $\begin{array}{c}80 \\
63-117\end{array}$ & $\begin{array}{c}17 \\
6-24\end{array}$ & $\begin{array}{c}32 \\
14-44\end{array}$ & $\begin{array}{c}29 \\
8-71\end{array}$ & $\begin{array}{c}3 \cdot 9 \\
2 \cdot 7-9 \cdot 1\end{array}$ & $\begin{array}{c}0 \cdot 8 \\
0 \cdot 6-2 \cdot 1\end{array}$ \\
\hline Barbiturate intoxication & 8 & 8 & $\begin{array}{c}56 \\
32-81\end{array}$ & $\begin{array}{c}33 \cdot 7 \\
31 \cdot 5-34.9\end{array}$ & $\begin{array}{c}89 \\
73-107\end{array}$ & $\begin{array}{c}11 \\
7-13\end{array}$ & $\begin{array}{c}27 \\
17-39\end{array}$ & $\begin{array}{c}16 \\
10-21\end{array}$ & $\begin{array}{c}6 \cdot 0 \\
3 \cdot 2-8 \cdot 3\end{array}$ & $\begin{array}{c}0.85 \\
0 \cdot 6-1 \cdot 1\end{array}$ \\
\hline
\end{tabular}


and CSF using enzymatic spectrophotometric analysis (Bergmeyer, 1963). CSF bicarbonate was determined by the Conway technique (Conway, 1950). Calculation of (a-v) $\mathrm{O}_{2}$ was made after determination of oxygen saturation percentage using saponin haemolysis and spectrophotometric analysis (Holmgren and Pernow, 1959). No correction for physically dissolved oxygen was performed. The arterial $\mathrm{PCO}_{2}\left(\mathrm{PaCO}_{2}\right)$ was determined using a Severinghaus $\mathrm{PCO}_{2}$ electrode. $\mathrm{PaCO}_{2}$ was measured at $38^{\circ} \mathrm{C}$ and corrected to body temperature using the Blood Gas Calculator (Severinghaus, 1966).

In cases of suspected brain death the EEG was recorded as previously described (Jørgensen and Brodersen, 1971).

From the first 10 minutes of the linearly recorded ${ }^{133}$ Xenon clearance curve, $\mathrm{CBF}_{10}$ was calculated using the height over area method (HøedtRasmussen et al., 1966). When using the multidetector instrument, a mean of all channels was used for $\mathrm{CMRO}_{2}$ calculation.

Studies in hypothermic man and animals have shown that $\mathrm{CMRO}_{2}$ decreases about $15 \%$ per degree centigrade and that there is a linear correlation between body temperature and $\log \mathrm{CMRO}_{2}$ (Bering, 1961; Olesen, in press). $\mathrm{CMRO}_{2}$ values obtained during hypothermia were therefore corrected to $37^{\circ}$ $\mathrm{C}$ using the equation (Olesen, in press): $\mathrm{CMRO}_{2}(1)$ $=\mathrm{CMRO}_{2}(2) \times 10^{\left(t_{1}-t_{2}\right) \times 0.067}$. Values of $\mathrm{CMRO}_{2}$ in febrile patients were not corrected, as no clear correction factor for hyperthermia was available in the literature.

\section{RESULTS}

PATIENTS IN COMA $\mathrm{CBF}-\mathrm{CMRO}_{2}$ Table 2 gives the median and ranges of $\mathrm{CBF}, \mathrm{CMRO}_{2}$, and related parameters in 38 patients, grouped according to the general diagnosis. Generally CBF was reduced but a wide range of CBF levels was observed. Barbiturate intoxications all had reduced $\mathrm{CBF}$ and lowered body temperatures as well. CBF values far above normal were seen in two patients with cardiac arrest. The $\mathrm{PaCO}_{2}$ levels were generally moderately hypocapnic.

Subnormal (a-v) $\mathrm{O}_{2}$ values were observed in all groups, whereas (a-v) $\mathrm{O}_{2}$ levels above normal were rarely met, and then only in combination with very low flows of the order of $10-20 \mathrm{ml}$./ $100 \mathrm{~g} / \mathrm{min} . \mathrm{CMRO}_{2}$ was reduced in all patients in coma to levels below $2.5 \mathrm{ml} . / 100 \mathrm{~g} / \mathrm{min}$ with most of the observations in the range $1.0-2.0$. $\mathrm{ml} . / 100 \mathrm{~g} / \mathrm{min}$. Patients with uncomplicated barbiturate intoxication usually had $\mathrm{CMRO}_{2}$ levels below $1.0 \mathrm{ml} . / 100 \mathrm{~g} / \mathrm{min}$, compatible with complete recovery.

The lumbar CSF pressures were within normal

TABLE 3

CSF ACID-BASE VARIABLES IN COMA AND BRAIN DEATH: MEDIAN AND RANGE

\begin{tabular}{|c|c|c|c|c|c|c|c|c|c|}
\hline & \multirow{2}{*}{$\begin{array}{l}\text { Patients } \\
\text { (no.) }\end{array}$} & \multirow{2}{*}{$\begin{array}{c}\text { Samples } \\
\text { (no.) }\end{array}$} & \multicolumn{4}{|c|}{$C S F$} & \multicolumn{3}{|c|}{ Blocd } \\
\hline & & & $\begin{array}{l}\text { Lactate } \\
(\text { mmol/l. })\end{array}$ & $\begin{array}{l}\text { Pyruvate } \\
\text { (mmol/l.) }\end{array}$ & $\frac{\text { Lactate }}{\text { pyruvate }}$ & $\begin{array}{c}\mathrm{HCO}_{3}^{-} \\
(\text {mmol/l. })\end{array}$ & $\begin{array}{c}\text { Arterial } \\
\text { lactate } \\
(\text { mmol/li.) }\end{array}$ & $\begin{array}{c}\text { Int. jug. } \\
\text { ven. } \\
\text { lactate } \\
\text { (mmol/l.) }\end{array}$ & $\begin{array}{l}\text { Average } \\
v \text {-a lac- } \\
\text { tate diff. } \\
\text { (mmolll.) }\end{array}$ \\
\hline Posthypoglycaemic coma & 3 & 3 & $\begin{array}{c}4 \cdot 05 \\
2 \cdot 86-4 \cdot 30\end{array}$ & $\begin{array}{c}0.360 \\
0 \cdot 274-0.425\end{array}$ & $\begin{array}{c}12 \cdot 0 \\
6 \cdot 7-14 \cdot 8\end{array}$ & $\begin{array}{c}16 \cdot 1 \\
15 \cdot 3-20 \cdot 0\end{array}$ & $\begin{array}{c}1 \cdot 24 \\
1 \cdot 10-2 \cdot 04\end{array}$ & $\begin{array}{c}1 \cdot 16 \\
1 \cdot 12-2 \cdot 33\end{array}$ & $\begin{array}{l}0 \cdot 08 \\
\text { SD } 0 \cdot 11 \\
\text { NS }\end{array}$ \\
\hline Cardiac arrest & 8 & 12 & $\begin{array}{c}4 \cdot 05 \\
2 \cdot 26-8 \cdot 71\end{array}$ & $\begin{array}{c}0 \cdot 240 \\
0 \cdot 150-0 \cdot 465\end{array}$ & $\begin{array}{c}16 \cdot 5 \\
11 \cdot 6-22 \cdot 1\end{array}$ & $\begin{array}{c}22 \cdot 3 \\
17 \cdot 9-27 \cdot 6\end{array}$ & $\begin{array}{c}1.41 \\
0.71-3.08\end{array}$ & $\begin{array}{c}1.42 \\
0.81-3 \cdot 35\end{array}$ & $\begin{array}{c}0.17 \\
\text { SD } 0 . C 4 \\
P<0.01\end{array}$ \\
\hline $\begin{array}{l}\text { Cardiac arrest and } \\
\text { barbiturate intoxication }\end{array}$ & 5 & 5 & $\begin{array}{c}3 \cdot 83 \\
1 \cdot 98-7 \cdot 29\end{array}$ & $\begin{array}{c}0 \cdot 275 \\
0 \cdot 144-0 \cdot 418\end{array}$ & $\begin{array}{c}17 \cdot 4 \\
13 \cdot 8-23 \cdot 6\end{array}$ & $\begin{array}{c}21 \cdot 6 \\
12 \cdot 6-23 \cdot 2\end{array}$ & $\begin{array}{c}1.93 \\
0.54-4.99\end{array}$ & - & - \\
\hline Barbiturate intoxication & 5 & 5 & $\begin{array}{c}1 \cdot 76 \\
1 \cdot 22-2 \cdot 54\end{array}$ & $\begin{array}{c}0 \cdot 111 \\
0 \cdot 101-0 \cdot 131\end{array}$ & $\begin{array}{c}15 \cdot 6 \\
11 \cdot 1-22 \cdot 4\end{array}$ & $\begin{array}{c}24 \cdot 1 \\
18 \cdot 5-27 \cdot 3\end{array}$ & $\begin{array}{c}1 \cdot 54 \\
0.98-2 \cdot 51\end{array}$ & $\begin{array}{c}1 \cdot 75 \\
1 \cdot 01-2 \cdot 34\end{array}$ & $\begin{array}{l}0 \cdot 06 \\
\text { SD } 0 \cdot 14 \\
\text { NS }\end{array}$ \\
\hline Brain death & 8 & 8 & $\begin{array}{c}7 \cdot 44 \\
2 \cdot 82-10 \cdot 99\end{array}$ & $\begin{array}{c}0.256 \\
0.093-0.420\end{array}$ & $\begin{array}{c}32 \cdot 4 \\
17 \cdot 5-49 \cdot 8\end{array}$ & $\begin{array}{c}17 \cdot 0 \\
10 \cdot 3-31 \cdot 8\end{array}$ & $\begin{array}{c}1 \cdot 73 \\
0 \cdot 74-3 \cdot 25\end{array}$ & $\begin{array}{c}2 \cdot 52 \\
0.95-2 \cdot 94\end{array}$ & $\begin{array}{l}0.32 \\
\text { SD 0.43 } \\
\text { NS }\end{array}$ \\
\hline $\begin{array}{l}\text { Normal values } \\
\text { Mean } \\
\text { SD }\end{array}$ & 13 & 13 & $\begin{array}{l}1 \cdot 54 \\
0.31\end{array}$ & $\begin{array}{l}0 \cdot 124 \\
0 \cdot 010\end{array}$ & $\begin{array}{r}12.3 \\
1.9\end{array}$ & $\begin{array}{r}23.6 \\
0.9\end{array}$ & $\begin{array}{l}0 \cdot 70 \\
0 \cdot 35\end{array}$ & - & - \\
\hline
\end{tabular}




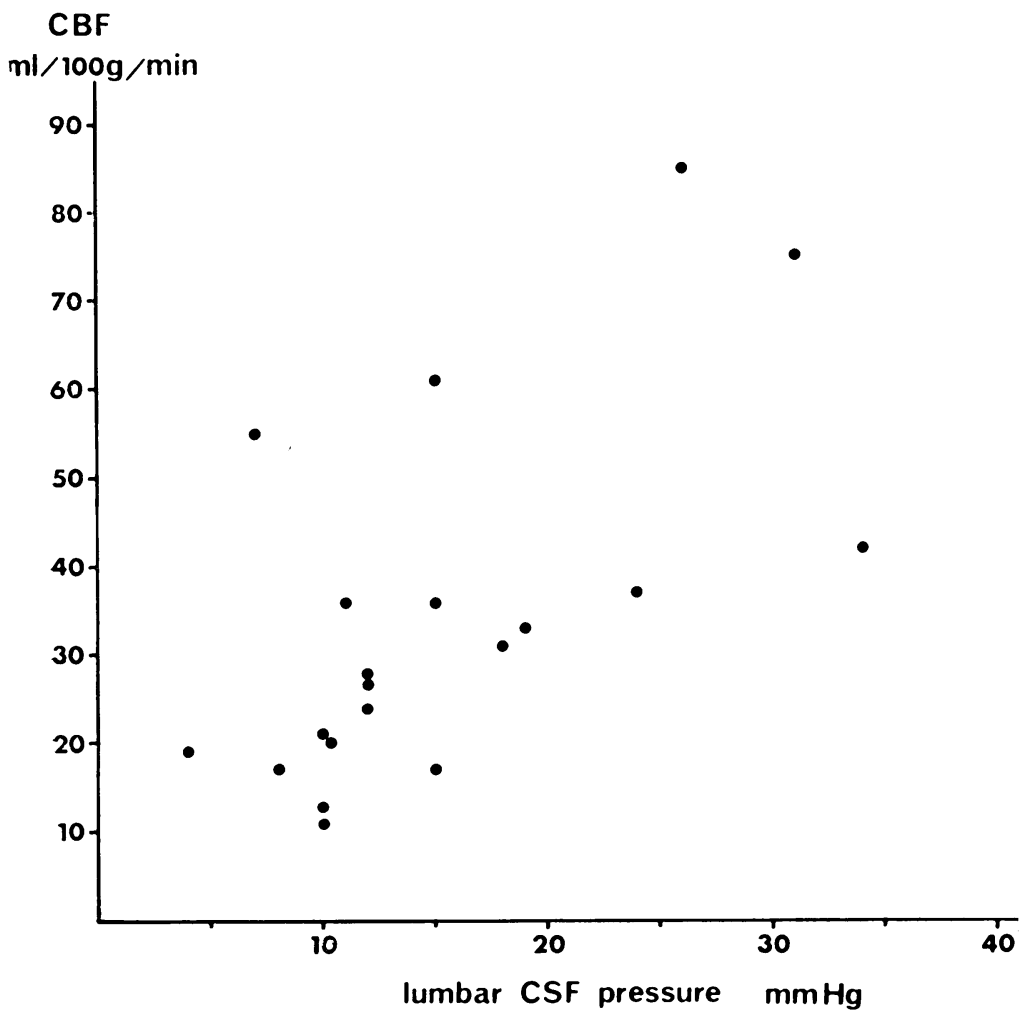

FIG. 1. The relationship between the lumbar $C S F$ pressure and $C B F$ in coma. The line of regression with a coefficient of correlation, $r=0.62$ was not shown because of uneven distribution of the observations.

limits except in four studies where moderately elevated pressures (about $30 \mathrm{mmHg}$ ) were observed. None of the head trauma patients had a lumbar puncture.

In every case of head trauma, cardiac arrest, or posthypoglycaemic coma where the multidetector instrument was applied, a strikingly uneven distribution of flow was noticed.

Cerebrospinal fluid The CSF data and blood lactate levels are given in Table 3. Patients with uncomplicated barbiturate intoxication had CSF lactate, pyruvate, lactate/pyruvate $(\mathrm{L} / \mathrm{P})$ ratios, and bicarbonate levels that did not deviate significantly from normal. The combination of hypocapnia and normal CSF bicarbonate levels in this group of patients suggests a CSF $\mathrm{pH}$ above normal.

The other groups studied all showed evidence of a CSF lactacidosis. Patients in posthypoglycaemic coma probably had increased CSF lactate levels because of respiratory insufficiency after correction of the hypoglycaemia. In cardiac arrest patients the CSF changes seemed to be independent of additional barbiturate overdose. The combination of increased CSF lactate and $\mathrm{L} / \mathrm{P}$ ratio in these patients pointed to the recent hypoxic-ischaemic episode. Wide ranges of lactate levels were observed, probably reflecting differences in the duration of the cardiac arrest and different time intervals from resuscitation to CSF sampling. An elevated arterial lactate concentration was noted in all the groups. Despite a large concentration gradient between CSF and arterial blood, only small $\mathrm{v}$-a lactate differences were found. This observation is in agreement with a rather low blood-brain barrier permeability for lactate (Oldendorf, 1972).

Correlations The wide CBF ranges could not be explained by differences in $\mathrm{PaCO}_{2}$, because there was no correlation between $\mathrm{PaCO}_{2}$ and $\mathrm{CBF}$.

Figure 1 shows the lumbar CSF pressures and CBF. It appears that the CSF pressure was not a 
CBF

$\mathrm{ml} / \mathrm{loog} / \mathrm{min}$

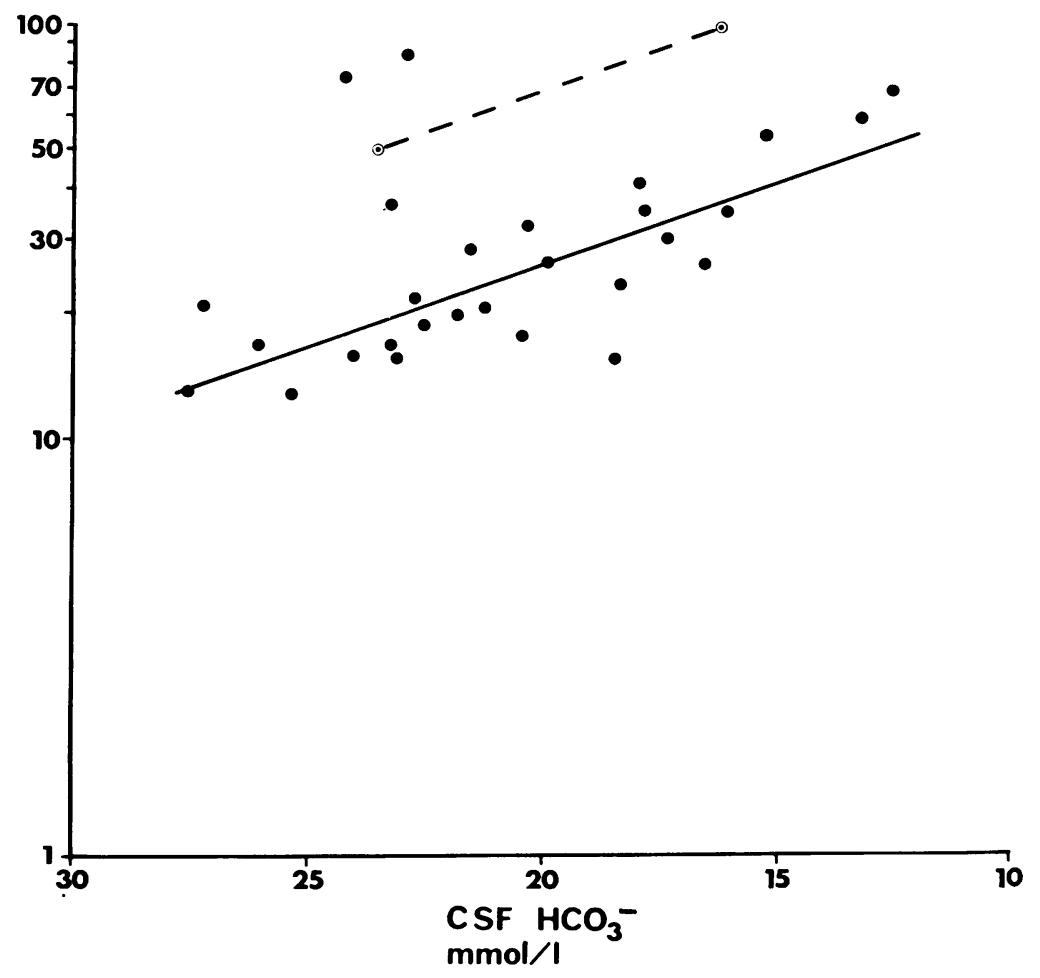

FIG. 2. The relationship between CSF bicarbonate and log CBF in coma. The line of regression: $y=\bar{y}$ $0 \cdot 04 x+2 \cdot 23, r=0 \cdot 8$, $P<0.001$. The broken line indicates an expected correlation for normal man. Assuming a doubling of flow at $\mathrm{PaCO}_{2} 60 \mathrm{mmHg}$, a CSF pH of 7.20 was calculated. Then a CSF bicarbonate of $16.3 \mathrm{mmol} / \mathrm{l}$. was calculated assuming $a$ $\mathrm{PaCO}_{2}$ of $40 \mathrm{mmHg}$ and a CSF $\mathrm{pH}$ of $7 \cdot 20$.

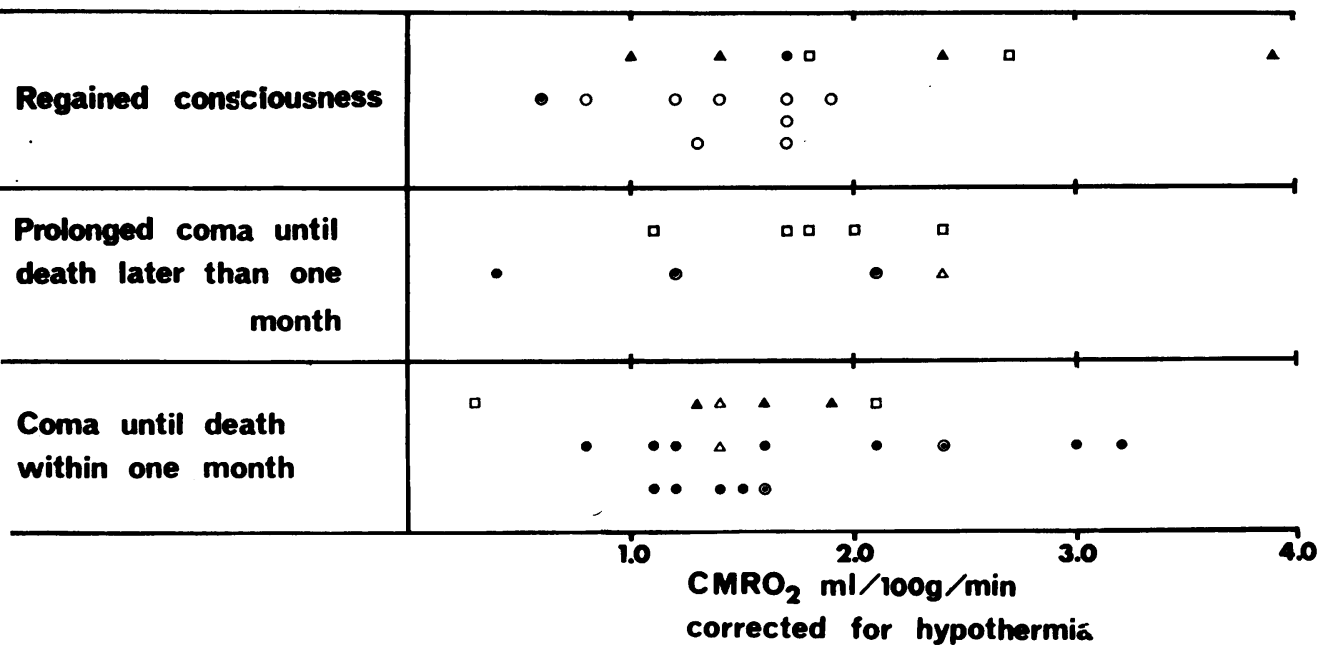

FIG. 3. Temperature corrected $\mathrm{CMRO}_{2}$ values in coma correlated with the outcome. $\square$ head trauma, $\Delta$ cerebrovascular lesions, $\triangle$ hypoglycaemia, $\bigcirc$ hypoxia, $\bigcirc$ barbiturate intoxication, $\odot$ barbiturate intoxication + cardiac arrest. 
limiting factor inducing low flow. On the contrary, the CSF pressure may be considered a function of CBF in this group of patients.

Figure 2 gives the relationship between the CSF bicarbonate and log CBF. Patients with $\mathrm{PaCO}_{2}$ levels in the range $18-44 \mathrm{mmHg}$ were included. All observations in Fig. 2 seemed to fit a linear correlation, except two studies in one patient. The linear CSF bicarbonate-log CBF correlation may be considered evidence of a $\mathrm{CSFpH}-\log \mathrm{CBF}$ correlation with some reservations (see Discussion).

No absolute correlation between $\mathrm{CBF}$ and prognosis was observed. Generally CBF below half of normal or considerably above normal was a bad prognostic sign, if barbiturate overdose or hypothermia were excluded.

Looking for a possible correlation between $\mathrm{CMRO}_{2}$ and the outcome, $\mathrm{CMRO}_{2}$ values were corrected for hypothermia (Fig. 3). There was a marked overlapping of the $\mathrm{CMRO}_{2}$ ranges in the three groups with a different outcome. When patients with barbiturate overdose were excluded, only $\mathrm{CMRO}_{2}$ levels below $1.0 \mathrm{ml} . / 100 \mathrm{~g} / \mathrm{min}$ seemed to predict a poor outcome. This was, however, observed in only three cases, two of which died within 24 hours whereas the third remained in an apallic state until death after seven months. The data shown in Fig. 3 indicate that $\mathrm{CMRO}_{2}$ measurements were of no practical value in predicting the prognosis in coma, not even when the effects of sedatives and body temperature were considered.

BRAIN DEATH Eighteen studies were performed in 17 cases of brain death. The CBF study in every case showed severely abnormal ${ }^{133} \mathrm{Xe}$ washout curves. The configuration of these curves indicated that the isotope did not reach the brain, and this was considered indirect evidence of cerebral circulatory arrest. The (a-v) $\mathrm{O}_{2}$ was reduced to a range of $0-5.5 \mathrm{vol} \%$ with a median of $1.3 \mathrm{vol}^{\circ} \%$.

A marked increase of the CSF lactate concentration was observed in brain death (Table 3), but there was some overlapping with the CSF lactate ranges seen in comatose patients after cardiac arrest. A striking increase of the CSF $\mathrm{L} / \mathrm{P}$ ratio was noticed only in brain death.

\section{DISCUSSION}

Our CBF, (a-v) $\mathrm{O}_{2}$, and $\mathrm{CMRO}_{2}$ results in acute head trauma, post-hypoglycaemic coma, and cardiac arrest corresponded with previous studies (Fazekas et al., 1951; Lindgren et al., 1968; Shalit et al., 1970, 1972; Bruce et al., 1972; Fieschi et al., 1972). The lowest CBF and $\mathrm{CMRO}_{2}$ levels in barbiturate intoxication were only about half of those previously reported (Malmlund, 1968; Bès et al., 1971). This may be explained by selection of patients. Our patients were considered the severest type of overdose. They all needed artificial ventilation, and their serum barbiturate concentrations ranged from 8 to $50 \mathrm{mg} / 100 \mathrm{ml}$. (read as aprobarbital or barbital). Their EEGs showed 'burst-suppression' with flat periods of 3 to 100 seconds.

We found no report in the literature on CSF data in patients after cardiac arrest, prolonged hypoglycaemia, or during barbiturate overdose. In animal experiments transient elevations of CSF lactate, pyruvate, and $\mathrm{L} / \mathrm{P}$ ratio have been demonstrated after either asphyxia or hypotension (Kaasik et al., 1970a, b). Such experimental conditions differ markedly from resuscitation of a patient suffering from cardiac arrest. The CSF changes of our cardiac arrest patients lasted several days, whereas similar CSF changes in the animal experiments lasted only minutes to hours.

It may be questioned whether the lumbar CSF pressures given in Fig. 1 really corresponded to the intraventricular fluid pressure. As most of the pressures were within normal limits, no major discrepancies would be expected. Fieschi et al. (1972) in head trauma patients with rather low intraventricular pressures found a correlation between the intraventricular fluid pressure and CBF similar to our Fig. 1. In patients with mass lesions and high intraventricular fluid pressure levels, the relationship between intraventricular fluid pressure and CBF may be more complex (Bruce et al., 1972).

We did not find a correlation between CBF and $\mathrm{PaCO}_{2}$, not even when the CBF values were corrected to a normal $\mathrm{CMRO}_{2}$ by multiplying by $3 \cdot 3 / \mathrm{CMRO}_{2}$. Since our patients had relatively stable $\mathrm{PaCO}_{2}$ levels for several hours, their CSF pH might be considered 'adapted' to the $\mathrm{PaCO}_{2}$ level. $\mathrm{PaCO}_{2}$ changes influence $\mathrm{CBF}$ by 
changes in the extracellular fluid $\mathrm{pH}$ around the brain arterioles (Skinhøj, 1966; Lassen, 1968). The CSF pH, which at a steady state is assumed to equal the $\mathrm{pH}$ of the brain extracellular fluid, is mainly determined by the ratio between bicarbonate and $\mathrm{CO}_{2}$. The latter rapidly crosses the blood brain barrier, whereas the bicarbonate ion is impeded. After a reduction of the $\mathrm{PaCO}_{2}$, the CSF $\mathrm{PCO}_{2}$ decreases and CSF pH increases. During some hours the CSF bicarbonate is gradually reduced and $\mathrm{CSF} \mathrm{pH}$ approaches normal. This sequence is usually named CSF $\mathrm{pH}$ adaptation.

As our patients were considered adapted to their $\mathrm{PaCO}_{2}$ level, a lack of correlation between $\mathrm{PaCO}_{2}$ and $\mathrm{CBF}$ was to be expected. In these circumstances, the finding of a close correlation between CSF bicarbonate and log CBF speaks in favour of the CSFpH determining $\mathrm{CBF}$, even in coma with the wide range of flows observed.

Based on the Henderson-Hasselbach equation, $\mathrm{pK}$ values, and solubility coefficients for $\mathrm{CO}_{2}$ (Mitchell et al., 1965), CSF bicarbonate, and estimates of CSF $\mathrm{PCO}_{2}$, we calculated the CSF $\mathrm{pH}$. We estimated the CSF $\mathrm{PCO}_{2}$ as $\mathrm{PaCO}_{2}$ plus $8 \mathrm{mmHg}$, which is the normal difference between $\mathrm{CSF} \mathrm{PCO}_{2}$ and $\mathrm{PaCO}_{2}$. There was also a linear correlation between calculated CSF $\mathrm{pH}$ and $\log$ CBF. It should be admitted, however, that the estimation of CSF $\mathrm{PCO}_{2}$ involves considerable uncertainty in patients with a brain lesion (Gordon and Rossanda, 1968). For this reason we preferred to show only data that were measured-that is, CSF bicarbonate and CBF.

The line of regression in Fig. 2 was situated below and parallel to a line of regression assumed to be valid for awake normal man. This means that changes of the CSF pH cannot account for a reduction of $\mathrm{CBF}$, when wakefulness changes to coma. Variations of CBF in comatose states seem, however, to depend upon the CSF pH.

It might be expected that in case of severe brain oedema, low CBF might occur in the presence of CSF and brain tissue acidosis (Frei et al., 1971). Such coma patients were not exposed to lumbar puncture in the present study because of the risk of herniation.

Two observations in one patient on the first and second day after cardiac arrest were situated far above all other observations in Fig. 2. It is tempting to suggest that the luxury perfusion
(Lassen, 1966) in this patient might have been caused by some other agent than the hydrogen ion. Potassium which has been shown to cause cerebral vasodilatation (Kuschinsky et al., 1972) might be suspected, but no analysis for CSF potassium concentration was performed in this patient.

A main purpose of this study was to analyse the relationship between $\mathrm{CMRO}_{2}$ and the prognosis in coma. Generally, our findings were in agreement with those of Shalit et al. (1970, 1972), Tabbador et al. (1972), and the study of Gordon and Bergval (1972). We also found that recovery was seen after $\mathrm{CMRO}_{2}$ depression to values below half of normal. Our study especially showed that $\mathrm{CMRO}_{2}$ levels below about onethird of normal were only followed by recovery if either hypothermia and/or sedatives were present. These factors significantly influence both $\mathrm{CBF}-\mathrm{CMRO}_{2}$ and the clinical examination. Body temperature and sedatives should therefore always be taken into account when evalua ting comatose patients.

Our data in Fig. 3 led us to conclude tha $\vec{B}$ CBF-CMRO ${ }_{2}$ measurements were of no help is predicting the outcome in comatose patients. W\& therefore find it without clinical implications te look further for critical $\mathrm{CMRO}_{2}$ levels.

BRAIN DEATH Although characteristic abnormalities were identified in every ${ }^{133} \mathrm{Xe}$ washout curve in brain death, we would not recommend this method for the diagnosis of brain death. The washout curve abnormalities were interpreted as indirect evidence of no $\mathrm{CBF}$, but the curve analysis might be inconclusive unless several precautions with regard to position of catheter and isotope injection were taken. Similar experience was published by Hadjidimos et al. (1969). Furthermore, the intra-arterial ${ }^{133} \mathrm{Xe}$ method measures CBF only supratentorially, which is not quite sufficient for a diagnosis of brain death.

The (a-v) $\mathrm{O}_{2}$ was of no value for the diagnosis of brain death, as suggested by Bès et al. (1969). Although usually reduced to below $3 \mathrm{vol}^{\circ} \%$ in brain death, similar levels were seen in patients with luxury perfusion.

CSF lactate levels seemed to be of no help either because of overlap with the range in cardiac arrest patients. Thus we were unable to 
confirm the suggestion by Paulson et al. (1972). It is the experience of several authors as well as ourselves that a four vessel angiography is the method of choice for cases where a prompt diagnosis of brain death is required irrespective of distracting lesions, sedation, or hypothermia (Jørgensen and Brodersen, 1971).

\section{REFERENCES}

Bergmeyer, H. U. (ed.) (1963). Methods of Enzymatic Analysis. Academic Press: New York.

Bering, E. A., Jr. (1961). Effect of body temperature change on cerebral oxygen consumption of the intact monkey. American Journal of Physiology, 200, 417-419.

Bès, A., Arbus, L., Lazorthes, Y., Escande, M., Delpla, M., and Vergnes, J. P. M. (1969). Hemodynamic and metabolic studies in 'coma dépassé'. A search for a biological test of death of the brain. In Cerebral Blood Flow, pp. 213215. Edited by M. Brock, C. Fieschi, D. H. Ingvar, N. A. Lassen, and K. Schürmann. Springer: Berlin.

Bès, A., Vergnes, J. P. M., Escande, M., Delpla, M., and Charlet, J. P. (1971). Cerebral blood flow and metabolism in three types of coma: apoplectic coma, barbituric coma, 'Coma dépassé'. In Brain and Blood Flow, pp. 138-142. Edited by R. W. R. Russell. Pitman: London.

Bruce, D. A., Miller, J. D., Langfitt, T. W., Goldberg, H. I., Stanek, A. E., and Vapalahti, M. (1972). rCBF and intracranial pressure in comatose patients. European Neurology, 8, 200-206.

Conway, E. J. (1950). Microdiffusion Analysis and Volumetric Error. 3rd edn. Crosby Lockwood: London.

Fazekas, J. F., Alman, R. W., and Parrish, A. E. (1951). Irreversible post-hypoglycemic coma. American Journal of Medical Science, 222, 640-643.

Fieschi, C., Beduschi, A., Agnoli, A., Battistini, N., Collice, M., Prencipe, M., and Risso, M. (1972). Regional cerebral blood flow and intraventricular pressure in acute brain injuries. European Neurology, 8, 192-199.

Frei, H. J., Pöll, W., Reulen, H. J., Brock, M., and Schürmann, K. (1971). Regional energy metabolism, tissue lactate content and rCBF in cold injury oedema. In Brain and Blood Flow, pp. 125-129. Edited by R. W. Ross Russell. Pitman: London.

Gordon, E., and Rossanda, M. (1968). The importance of the cerebrospinal fluid acid-base status in the treatment of unconscious patients with brain lesions. Acta Anaesthesiologica Scandinavica, 12, 51-73.

Gordon, E., and Bergvall, U. (1972). Cerebral blood flow and oxygen uptake in patients with brain lesions. European Neurology, 8, 213-218.

Hadjidimos, A. A., Brock, M., Baum, P., and Schürmann, K. (1969). Cessation of cerebral blood flow in total irreversible loss of brain function. In Cerebral Blood Flow, pp. 209-212. Edited by $M$. Brock, C. Fieschi, D. H. Ingvar, N. A. Lassen, and K. Schürmann. Springer: Berlin.

Holmgren, A., and Pernow, B. (1959). Spectrophotometric measurement of oxygen saturation of blood in the determination of cardiac output. A comparison with the Van Slyke method. Scandinavian Journal of Clinical and Laboratory Investigation, 11, 143-149.

Høedt-Rasmussen, K., Sveinsdottir, E., and Lassen, N. A. (1966). Regional cerebral blood flow in man determined by intra-arterial injection of radioactive inert gas. Circulation Research, 18, 237-247.

Ingvar, D. H., and Brun, A. (1972). Das komplette apallische Syndrom. Archiv für Psychiatrie und Nervenkrankheiten, 215, 219-239.
Jørgensen, E. O., and Brodersen, P. (1971). Kriterier for død. Nordisk Medicin, 86, 1549-1560.

Kaasik, A. E., Nilsson, L., and Siesjö, B. K. (1970a). The effect of asphyxia upon the lactate, pyruvate and bicarbonate concentrations of brain tissue and cisternal CSF, and upon the tissue concentrations of phosphocreatine and adenine nucleotides in anesthetized rats. Acta Physiologica Scandinavica, 78, 433-447.

Kaasik, A. E., Nilsson, L., and Siesjö, B. K. (1970b). The effect of arterial hypotension upon the lactate, pyruvate and bicarbonate concentrations of brain tissue and cisternal CSF, and upon the tissue concentrations of phosphocreatine and adenine nucleotides in anesthetized rats. Acta Physiologica Scandinavica, 78, 448-458.

Kety, S. S. (1949). The physiology of the human cerebral circulation. Anesthesiology, 10, 610-614.

Kuschinsky, W., Wahl, M., Bosse, O., and Thurau, K. (1972). Perivascular potassium and $\mathrm{pH}$ as determinants of local pial arterial diameter in cats: a microapplication study. Circulation Research, 31, 240-247.

Lassen, N. A. (1959). Cerebral blood flow and oxygen consumption in man. Physiological Reviews, 39, 183-238.

Lassen, N. A. (1966). The luxury-perfusion syndrome and its possible relation to acute metabolic acidosis localised within the brain. Lancet, 2, 1113-1115.

Lassen, N. A. (1968). Brain extracellular $\mathrm{pH}$ : the main factor controlling cerebral blood flow. Scandinavian Journal of Clinical and Laboratory Investigation, 22, 247-251.

Lindgren, S., Petersén, I., and Zwetnow, N. (1968). Prediction of death in serious brain damage. Acta Chirurgica Scandinavica, 134, 405-416.

Malmlund, H. O. (1968). Cerebral blood flow and oxygen consumption in barbiturate poisoning. Acta Medica Scandinavica, 184, 373-377.

Mitchell, R. A., Herbert, D. A., and Carman, C. T. (1965). Acid-base constants and temperature coefficients for cerebrospinal fluid. Journal of Applied Physiology, 20, 27-30.

Oldendorf, W. H. (1972). Blood brain barrier permeability to lactate. European Neurology, 6, 49-55.

Olesen, J. Cerebral blood flow. Methods and measurements, regulation, effect of drugs and changes in disease. Review of 10 years literature. (In press.) FADL: Copenhagen.

Olesen, J., Paulson, O. B., and Lassen, N. A. (1971). Regional cerebral blood flow in man determined by the initial slope of the clearance of intra-arterially injected ${ }^{133} \mathrm{Xe}$. Stroke, 2 , 519-540.

Paulson, O. B., Cronqvist, S., Risberg, J., and Jeppesen, F. I. (1969). Regional cerebral blood flow: a comparison of 8-detector and 16-detector instrumentation. Journal of Nuclear Medicine, 10, 164-173.

Paulson, G. W., Wise, G., and Conkle, R. (1972). Cerebrospinal fluid lactic acid in death and in brain death. Neurology (Minneap.), 22, 505-509.

Plum, F., and Posner, J. B. (1972). The Diagnosis of Stupor and Coma. 2nd edn. Davis: Philadelphia.

Severinghaus, J. W. (1966). Blood gas calculator. Journal of Applied Physiology, 21, 1108-1116.

Shalit, M. N., Beller, A. J., and Feinsod, M. (1972). Clinical equivalents of cerebral oxygen consumption in coma. Neurology (Minneap.), 22, 155-160.

Shalit, M. N., Beller, A. J., Feinsod, M., Drapkin, A. J., and Cotev, S. (1970). The blood flow and oxygen consumption of the dying brain. Neurology (Minneap.), 20, 740-748.

Skinhøj, E. (1966). Regulation of cerebral blood flow as a single function of the interstitial $\mathrm{pH}$ in the brain. Acta Neurologica Scandinavica, 42, 604-607.

Tabbador, K., Bhushan, C., Pevsner, P. H., and Walker, A. E. (1972). Prognostic value of cerebral blood flow and cerebral metabolic rate of oxygen in acute head trauma. Journal of Trauma, 12, 1053-1055. 